IJMS 17 (1), 55-67 (2010)

\title{
DIVIDEND ANNOUNCEMENTS AND CONTAGION EFFECTS: AN INVESTIGATION ON THE FIRMS LISTED WITH DHAKA STOCK EXCHANGE
}

\author{
M. ABU MISIR \\ Department of Finance \\ Jagannath University Dhaka
}

\begin{abstract}
Changes in dividend convey information about the earnings of the announcing firm which in turn affect the price. Security price depends on current earnings, past earnings, and future prospect of earnings. Dividend relevant theory postulates that dividend policy, dividend initiation and changes in dividend carry information about the market value of the announcing firms. Accordingly, an unexpected increase in dividends conveys positive information about the future profitability of the firm and vice versa. Firm's management is better informed than the market about the future prospects of their firm and therefore, their action relating to any financing decision conveys information to the investors. The principal purpose of this study was to examine the intra-industry information effects of announcements of dividend initiations of the firms associated with Dhaka Stock Exchange (DSE). To test this hypothesis, we used Herfindahl Index and Tobin's q ratio. The study found that the intra-industry effects of dividend revisions are apparent.
\end{abstract}

Keywords: Industry rivals; announcing firms; dividend changes; rivals' reactions; prediction error; cumulative average abnormal return; announcement date.

\section{Introduction}

The general beliefs of the security investors imply that the announcement of dividends by a firm could affect the stock prices of industry rivals. The general assumption of participants of security markets is that large revisions in dividends accompanied by stock price reactions for industry rivals of the announcing firms. Information transfers can provide contagion effects on rivals across the industry. Capital assets in the securities markets are priced on the basis of expected cash flows to be received in the form of cash receipts and capital appreciation in future time periods. All rational investors could 
use all the available information about the securities being traded in the market. A market is called efficient if the prices of all the securities quickly and fully reflect all the available and reasonably obtained information about the market and the subject securities as well. This concept of pricing of the capital assets postulates that investors will assimilate all information regardless of its categories into prices in making their buy and sell decisions. Foster (1981), in this connection, showed that earnings information of an individual firm in the industry conveys information about other firms in the same industry. This postulates that the earnings information disclosed by one firm in the same industry affect the price of another security. Intraindustry information transfers, therefore, is also documented for a number of information releases including disclosures of corporate earnings, dividends, accounting, and other inside information.

Bowen, Castanias, and Daley (1983) found that intra-industry formation transfer documents for a number of predisclosures like sales announcements, earnings release, and management forecasts about the future earnings. They found the impact of dividends on the stock prices of the rivals. The impacts of mergers and acquisitions of the firms on stock prices of other firms were documented by Eckbo (1983), Olsen, Dietrich, and Bernerd (1985), Joh and Lee (1992) postulated the effect of sales announcements on the rival firms within the same industry. Swary (1986) depicted the consequence effects of regulatory actions on other firms within the industry. Baginski (1987), Han, Wild, and Ramesh (1989) experienced the impacts of management forecasts on the stock prices of industry rivals. On going-private transactions as seen by Slovin, Sushka, and Poloncheck (1991) carry impacts on the prices of rivals within the industry. Consequently, the impact of dividend changes on the rival firms was examined by Firth (1996). In this connection, Howe and Shen (1998) examined the effects of dividend initiations on rivals. Subsequently, Paul, Starks, and Yoon (1998) tested the dividend announcement effects on the other firms within the same industry. They documented the stock price reactions to the intra-industry information transfers due to the contagion or competition between the firms. They also documented that the rival firms' stock price reactions tend to be the same direction as the announcing firm's price reaction. This may happen as the result of the release of information on the overall wealth of the industry. On the other hand, opposite circumstances may, therefore, be considered due to the result of shifts in the industry's competitive balance. In this connection, firms within the industry show a negative stock price reaction to the bankruptcy announcement of a rival (Lang \& Stulz, 1992). This indicated that factors leading to bankruptcy or any accident or event that carry bad news for the firm are industry-wide. They, however, show a positive reaction to the price of the rivals to the bankruptcy announcement where they indicate that competitive effects are more important. Szewczyck (1992) found that rivals have significant contagion effects to the announcements of seasoned issues. Seasoned issues

56 IJMS 17 (1), 55-67 (2010) 


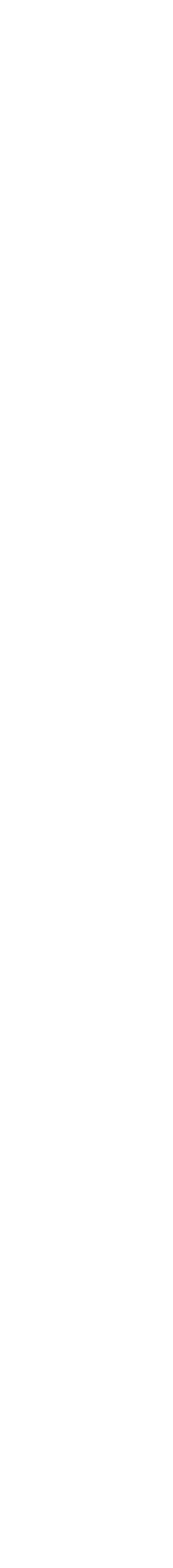

refer to the additional financing through initial public offerings (IPOs) by the existing companies. The pattern of raising and disbursement of cash to the shareholders of the announcing firms react to security prices of the rivals. For example, share repurchases refer to the situation where the firms buy back the securities from the owners. In this situation, the rivals' reactions are considered to be opposite following the announcements of repurchases. Hertzel (1991) found very little or no reaction at all to such announcements.

A large number of studies by Pettit (1972), Eades, Hess, and Kim (1985), Kalay and Loewenstein (1985-1986), Aharony and Swary (1980), Asquith and Mullins (1983), Bajaj and Vijh (1990), Yoon and Starks (1995) showed that management forecasts as well as the announcement of dividend changes convey information about the value of the announcing firms and the rival firms within the industry as well. Bhattacharya (1979) and Kalay (1980) showed that the value of the firm is related to the announcement of dividends, i.e. value of the subject firm depends on the amount of dividends declared. John and Williams (1985), and Miller and Rock (1985) argued that managers (also the directors, major shareholders, and accountants) have access to information about the firm's inside that the outsiders do not have. The most important factor in the firm's dividend policy is the anticipated level of the firm's future earnings and the pattern of past dividends. Dividend changes assumed to be such inside information result in the positive stock price changes for the firms announcing dividend increases. However, the announcements of dividends and the dividend changes disclose information relevant for the announcer's rivals. The impact on the rival firm depends on whether the information has a net contagion or a competitive effect. A contagion effect is a result of firm's returns, which is driven by common factors, i.e. the extent to which firms in that industry share inputs, outputs, production process, financial market, and labour markets. Information disclosure of one firm, like dividend revisions, could provide information about these factors, eliciting similar stock price revisions for all firms in the industry. In this connection, Marsh and Merton (1987) suggested that contagion effects may result if the individual firm uses industry practices as targets for their own dividend policies with a view to maximising the wealth for the shareholders. As a result, the announcement of a dividend change conveys signal on the likelihood that a rival firm will change its dividend in the same direction. A dividend increase might disclose the strongliness of the announcing firm, more than previously anticipated. A dividend decrease, on the other hand, might disclose the weakness relative to certain rivals as well as negative industry information. Furthermore, either of the contagion effects (positive or negative) on industry rivals can be attenuated or reversed by the competitive effects. Jensen and Johnson (1995) argued that rivals having little dominance in the market and few resources experience large offsetting negative competitive effects when a rival announces a dividend increase and weak firms experience a small 
positive competitive effect that only partially offsets the negative industry information in a dividend-decrease announcement when a rival decreases its dividend. Activities of a firm around dividend decreases can negatively affect the firm's future competitive position. Lang and Litzenberger (1989) applied the model of Miller and Modigliani (1966) to test the effects of dividend on the valuation of the announcing firms.

The purpose of the our study was to examine whether there are disparate reactions to the rivals of dividend announcing firms listed with the Dhaka Stock Exchange during the period under study. This study used the sample of dividend increases and decreases showing the same announcement, which may have diverse effects within the same industry of DSE. The contagion effects dominate for some rivals. The contagion effects are offset by competitive shifts for other rivals in the same industry.

The key distinctions are the relative market power and the growth options of the rivals vis-à-vis the announcing firm. Using some relevant sample, rivals' reactions may or may not be evident. The firm characteristics can influence whether rival firms have a contagion or competitive reaction. Regardless of how refined the industry definition is, the implication is that there may still be cross-sectional differences in the information transfers.

\section{Data and Methodology}

\section{Model Specification}

Negative information about the industry specification raises the question of which one of the announcer's industry rivals is in the weakest position to respond to the announcing firm's weakness and to withstand any industrywide bad news. Lang and Litzenberger (1989) argued that firms performing slightly better in the industry are less able to withstand the signaled industrywide troubles than the firms performing better. The firms without flexibility in their future operations are not as well prepared to respond effectively to the new industry environment. Paul et al. (1998) found that firms lacking - current market power relative to their industry rivals and also those lacking options in their future operations will be most severely affected by their bad news about their rivals.

The performance of an industry might be estimated through a commonly used measure based on the extent of concentration in the market shares called the Herfindahl Index. The theoretical concept of Herfindahl Index derives from cournot competition under which the total profits of an industry from existing operations are measured in its Herfindahl Index. It is estimated as the sum of squared market shares for all firms in an industry. Then, the market power of a particular industry rival relative to an announcing firm

58 IJMS 17 (1), 55-67 (2010) 


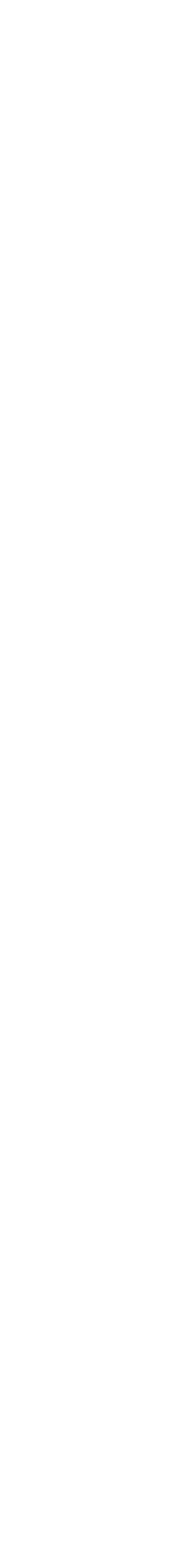

is measured by comparing their contribution to the industry's Herfindahl Index. However, the contribution of an individual firm's Herfindahl is an index in the market power of that firm relative to its industry rivals. However, Kane, Lee and Marcus (1984), and Venkatesh (1989) found that earnings and dividend announcements have an interactive effect and thus the requirement of non-contaminating earnings announcements is particularly appropriate. The other important data observations needed for the analyses are the Tobin's q market share of industry revenue data. The announcing firms and the industry rivals should be included in the general price index. To estimate the stock price reaction for the announcing firm, the study is devoted to use the market model, one of the derivatives of capital asset pricing model (CAPM) in order to estimate the prediction error for the firm on a particular day. The specification of the market model is:

$$
\mathrm{r}_{i t}=\alpha_{i}+\beta_{i} \mathrm{r}_{m t}+\varepsilon_{i t}
$$

where,

$\mathrm{r}_{i t}=$ return of stock $\mathrm{i}$ at time $\mathrm{t}$,

$\mathrm{r}_{m t}=$ return of the market at time $\mathrm{t}$,

$\varepsilon_{i t}=$ error term of stock $\mathrm{i}$ at time $\mathrm{t}$, and

$\alpha_{i}, \beta_{i}$ are market model parameters.

The residual or prediction error can easily be found by using the mechanism as defined and used by Bajaj and Vijh (1990):

$$
\varepsilon_{i t}=\mathrm{r}_{i t}-\alpha_{i}-\beta_{i} \mathrm{r}_{m t}
$$

With a view toestimating theintra-industryeffectof dividend announcements, we can construct an equally weighted portfolio of the rival's shares for each announcement. Therefore, such a portfolio of the rival firms provides a powerful test as it averages over the random noise in individual rivals' stock returns. To test such portfolio effects, we divided the industry rival portfolios into subsamples according to the two defining firm competitive effects with, Tobin's q ratio and the Herfindahl contribution explaining the rival firms' reactions. We first divided the rival firms into two subsamples according to whether their Tobin's q is greater than or less than the announcing firm's q ratio. Thereafter, we subdivided each subsample into two more subsamples according to whether the rival's Herfindahl contribution is greater or less than the announcing firm's Herfindahl contribution to estimate the prediction errors for four subsample portfolios. Even clustering is inherent in an investigation of rivals' stock price reactions. Then we obtained the cumulative average prediction error, which we calculated by averaging the prediction error across firms (or portfolio) and acumulating over the announcement day and the previous day. The standardised prediction error approach developed by Dodd and Warner (1983) was applied to test the statistical significance. 


\section{Data Specification}

In this section, we describe the samples of dividend initiating and rival firms by applying statistical tools. To assess the intra-industry effect of dividend announcements, we adopted an event study methodology. The first step in the analysis was to use a sample of dividend increase and dividend decrease announcements of the firms listed with DSE obtained from the daily record book of DSE. Dividend changes for a variety of reasons depending on the management earnings forecasts and many anticipated events as well. With a view to testing the reaction of the stock prices to the dividend change announcement, it is essential to obtain the dividend announcement date, which is usually referred to as day 0 . We obtained the daily return data for the trading days around the dividend announcement for the announcing firms and the industry rivals from the daily return record book kept by DSE. To make ensure that our sample is relatively free of contaminating announcements, the announcing firms must not have either any major financing or investment announcements on the dividend announcement day, or an earnings announcement within a week of the dividend announcement, or a stock split or stock dividend within a month.

The study covers the observations during the period from January 1991 to December 2005. During this period, 105 observations announced dividend increase and 77 observations announced dividend decrease. So, the study covers a total of 182 announcing observations. Also during this period 135 observations were found suitable as industry rivals during the time dividend increase, while a total number of 95 observations of industry rivals were found at the time of dividend decrease.

\section{Empirical Test and Results}

Table 1 presents the cumulative average abnormal returns as percentages for 105 observations announcing dividend increase and 77 observations announcing dividend decrease during January 1991 to December 2005. The cumulative average returns for 135 observations of industry rival firms during the time dividend increase and a total number of 95 observations of industry rival firms at the time of dividend decrease were estimated. Table 1 depicts the stock price reaction for the announcing firms as well as for the portfolio for the industry rival firms. In panel A of Table 1, we present the sequence of the dividend increase of the announcing firms and results of the dividend decrease of the same are shown in panel $\mathrm{B}$. The table shows that the observations of the announcing firms experience substantial abnormal returns at the time of their dividend change announcement. About $65 \%$ of observations of the announcers and $50 \%$ of the observations of the rival portfolios have positive abnormal returns at the time of announcement. Before dividend announcements, $58 \%$ of observations among the announcers and $52 \%$ of the rival portfolios also have positive abnormal returns in case of dividend increases. However, all the observations from both announcers

60 IJMS 17 (1), 55-67 (2010) 


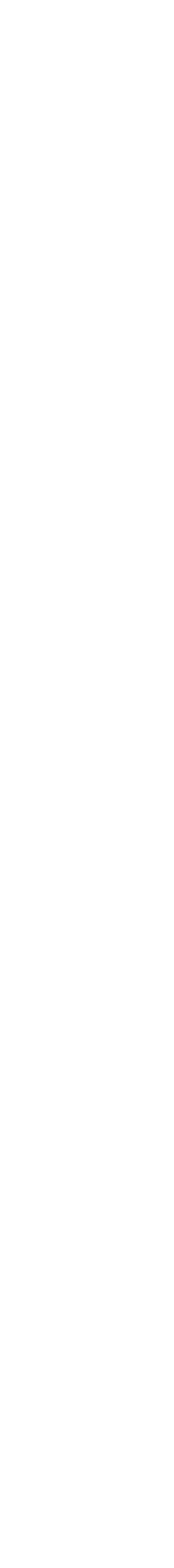

and rival portfolios have overall positive abnormal returns around dividend announcements in case of dividend increase.

Panel B of Table 1 shows that the observations of the industry rivals tend to react negatively to the observations of the announcing firm's dividend decrease. Panel B of Table-1 shows that about 33\% of observations of the rival portfolio have negative abnormal returns at the time of announcement, but $42 \%$ of observations of the same also have the negative abnormal returns before the announcements of dividends. In contrast, $11 \%$ and $29 \%$ of observations of the announcers have negative abnormal returns at the time of announcements and before announcements, respectively. However, all the observations from both announcers and rival portfolios have negative abnormal returns both at the time of and before the announcements of dividend decrease.

Table 1

Cumulative Abnormal Returns for Announcing Firms and Non-announcing Industry Rivals around the Dividend Announcement

\begin{tabular}{|c|c|c|c|c|c|c|}
\hline \multicolumn{7}{|c|}{ Panel-A: Announcements of Dividend Increase } \\
\hline \multicolumn{3}{|c|}{ Announcer } & \multirow[b]{2}{*}{ Period } & \multicolumn{3}{|c|}{ Rival Portfolio } \\
\hline$-15,-2$ & $-2,0$ & $+1,+15$ & & $-15,-2$ & $-2,0$ & $+1,+15$ \\
\hline 2.48 & 1.84 & 2.12 & CAARs & .52 & 1.21 & .05 \\
\hline 3.01 & 5.52 & 3.56 & z-statistics & 1.02 & .95 & .75 \\
\hline 58 & 65 & 55 & $\%$ & 52 & 50 & 49 \\
\hline \multicolumn{7}{|c|}{ Panel-B: Announcements of Dividend Decrease } \\
\hline \multicolumn{3}{|c|}{ Announcer } & & \multicolumn{3}{|c|}{ Rival Portfolio } \\
\hline$-15,-2$ & $-2,0$ & $+1,+15$ & Period & $-15,-2$ & $-2,0$ & $+1,+15$ \\
\hline-3.20 & -7.02 & 2.50 & CAARs & -1.45 & -2.37 & .95 \\
\hline-6.23 & -12.87 & 3.45 & z-statistics & -2.56 & -2.97 & .85 \\
\hline 29 & 11 & 55 & $\%$ & 42 & 33 & 45 \\
\hline
\end{tabular}

Notes. i) Period refers to the days relative to dividend announcement.

ii) CAARs refer to the cumulative average abnormal returns.

In addition to the results found for the rival portfolios, now we focus on whether a combination of contagion and competitive effects exists within an industry. Table 2 shows the results indicating the industry rival reactions. Panel A of Table 2 exhibits that for dividend increase, only rivals with a larger Tobin's q than the announcing firms' value have larger Herfindahl contribution. These rivals experience a significant positive two-day cumulative average prediction error of $0.52 \%$, while the reactions for others are closer to zero. In contrast, Panel B of Table 2 shows that in case of dividend decrease, only rivals whose Tobin's qs and Herfindahl contributions are smaller than the announcing firms' experience a significant reaction. These rivals experience a significant negative two-day cumulative average

IJMS 17 (1), 55-67 (2010) 
predictive error of $1.5 \%$; where as the reactions for others are insignificantly different from zero. The results of Table 2 indicated that the stock market of Bangladesh, particularly Dhaka Stock Exchange, infers significant information from dividend announcements for some industry rivals. The results indicated that significant stock price reactions occur for those rivals having competitive effects offsetting the contagion effects of the dividend announcements. We may further extend our study by saying that the stronger rivals seem to be less likely to place at a competitive disadvantage when an announcer reveals a positive signal. Similarly, weaker rivals are least likely to gain a competitive advantage when an announcer reveals a negative signal.

Table 2

Abnormal Returns to Subsamples of Rival Portfolio to the Announcement of Dividend Changes

\begin{tabular}{|c|c|c|c|}
\hline & & $\begin{array}{c}\text { Rivals' Tobin's q> } \\
\text { Announcer's Tobin's q }\end{array}$ & $\begin{array}{c}\text { Rivals' Tobin's q< } \\
\text { Announcer's Tobin's q }\end{array}$ \\
\hline \multirow{4}{*}{$\begin{array}{l}\mathrm{R} \text { i v a } 1 \mathrm{~s}^{\prime}{ }_{-} \mathrm{H} \mathrm{C} \mathrm{C} \\
\text { Announcer's_HC }\end{array}$} & CAAR & 0.52 & 0.10 \\
\hline & z-statistics & 2.35 & 1.05 \\
\hline & $\%$ & 60 & 52 \\
\hline & $\mathrm{N}$ & 75 & 90 \\
\hline \multirow{4}{*}{$\begin{array}{l}\mathrm{R} \text { i v a } 1 \mathrm{~s}{ }^{\prime},-\mathrm{H} \mathrm{C}_{-} \\
\text {Announcer's_HC }\end{array}$} & CAAR & 0.22 & -0.25 \\
\hline & z-statistics & 0.20 & -0.60 \\
\hline & $\%$ & 50 & 48 \\
\hline & $\mathrm{N}$ & 100 & 105 \\
\hline \multicolumn{4}{|c|}{ Panel-B: Announcements of Dividend Decrease } \\
\hline & & $\begin{array}{c}\text { Rivals' Tobin's q> } \\
\text { Announcer's Tobin's q }\end{array}$ & $\begin{array}{c}\text { Rivals' Tobin's q< } \\
\text { Announcer's Tobin's q }\end{array}$ \\
\hline \multirow{5}{*}{$\begin{array}{l}\mathrm{R} \text { i v a } 1 \mathrm{~s}{ }^{\prime}{ }_{-} \mathrm{H} \mathrm{C} \mathrm{>} \\
\text { Announcer's_HC }\end{array}$} & CAAR & 0.52 & -0.08 \\
\hline & z-statistics & 1.20 & -0.50 \\
\hline & $\%$ & 55 & 45 \\
\hline & $\mathrm{N}$ & 60 & 40 \\
\hline & CAAR & 0.12 & -1.50 \\
\hline \multirow{3}{*}{$\begin{array}{l}\text { R i v a l s '_ }{ }^{\prime} \mathrm{C} \mathrm{C}< \\
\text { Announcer's_HC }\end{array}$} & Z-statistics & -0.32 & -3.20 \\
\hline & $\%$ & 40 & 32 \\
\hline & $\mathrm{N}$ & 100 & 80 \\
\hline
\end{tabular}

Notes. i) HC stands for Herfindahl Contribution.

ii) CAAR stands for cumulative average abnormal returns.

iii) Percentages (\%) refer to positive abnormal returns.

iv) $\mathrm{N}$ stands for number of industry rival-firm portfolios.

62 IJMS 17 (1), 55-67 (2010) 


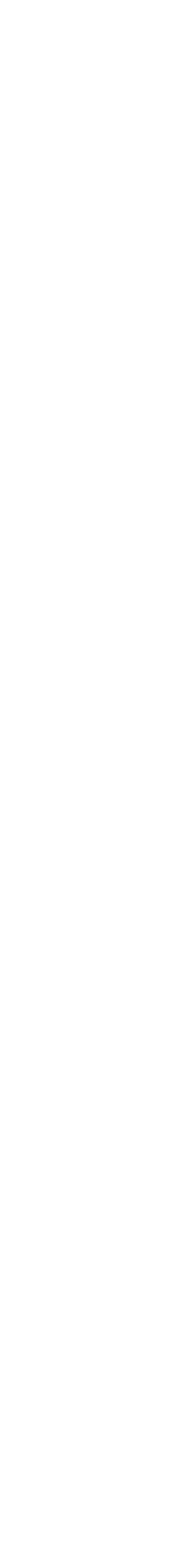

Table 3 portrays two-day mean cumulative average abnormal returns as percentages for industry rival firms at the time of dividend declaration during the period under study. Abnormal returns are derived from the market model. We constitute subsamples according to whether the rivals' responses are hypothesised to be in the same direction as the announcer's reaction or in the opposite direction. We hypothesised that for the announcement of dividend increase, rivals with large Herfindahl contributions and large Tobin's qs relative to the announcers have a reaction in the same direction, and those with small Herfindahl contributions and small Tobin's qs have a reaction in the opposite direction. For dividend decrease announcements, we hypothesised that the rivals with small Herfindahl contributions and small Tobin's qs relative to the announcers have reaction in the same direction, and those with large Herfindahl contributions and large Tobin's qs have reactions in the opposite direction. Table 3 reveals that all observations of the announcements of dividend increase and decrease, the last column of Panel A evidences that the two-day cumulative abnormal prediction errors of rivals for which competitive effects would be least likely to offset contagion effects is $0.80 \%$, indicating that reactions in the same direction, as hypothesised for the announcer, are positive. On the other, the rivals experiencing the largest offsetting competitive effects have a negative $-0.36 \%$ mean two-day reaction, which is not significantly differing from zero. The last column of Panel B of Table 3 shows a t-test of the difference in the means between the market reactions for the two subsamples confirming that they are significantly different at the 0.01 level of significance. The evidence suggests that the effects of shifts in an industry's competitive balance should be most evident in the industries where the rivalries of which are most important and such industries have large values of the Herfindahl Index. Columns 3 and 4 of Table 3 reveal that the industries with above-median values of the Herfindahl Index experience a greater difference between the two types of rivals' reactions, indicating that these industries are stronger in terms of competitive effects than those with below-median values of the Herfindahl Index. Table 3 also shows that the difference between the mean cumulative abnormal prediction errors for industry rivals showing contagion effects versus rivals having contagion effects offset by competitive effects is $1.80 \%$ subject to the industries having above-median Herfindahl Index values. In contrast, for industries with below-median Herfindahl Index, the corresponding value is $0.80 \%$. 
Table 3

Hypothesis Tests for Abnormal Returns of Industry Rivals on Dividend Announcements

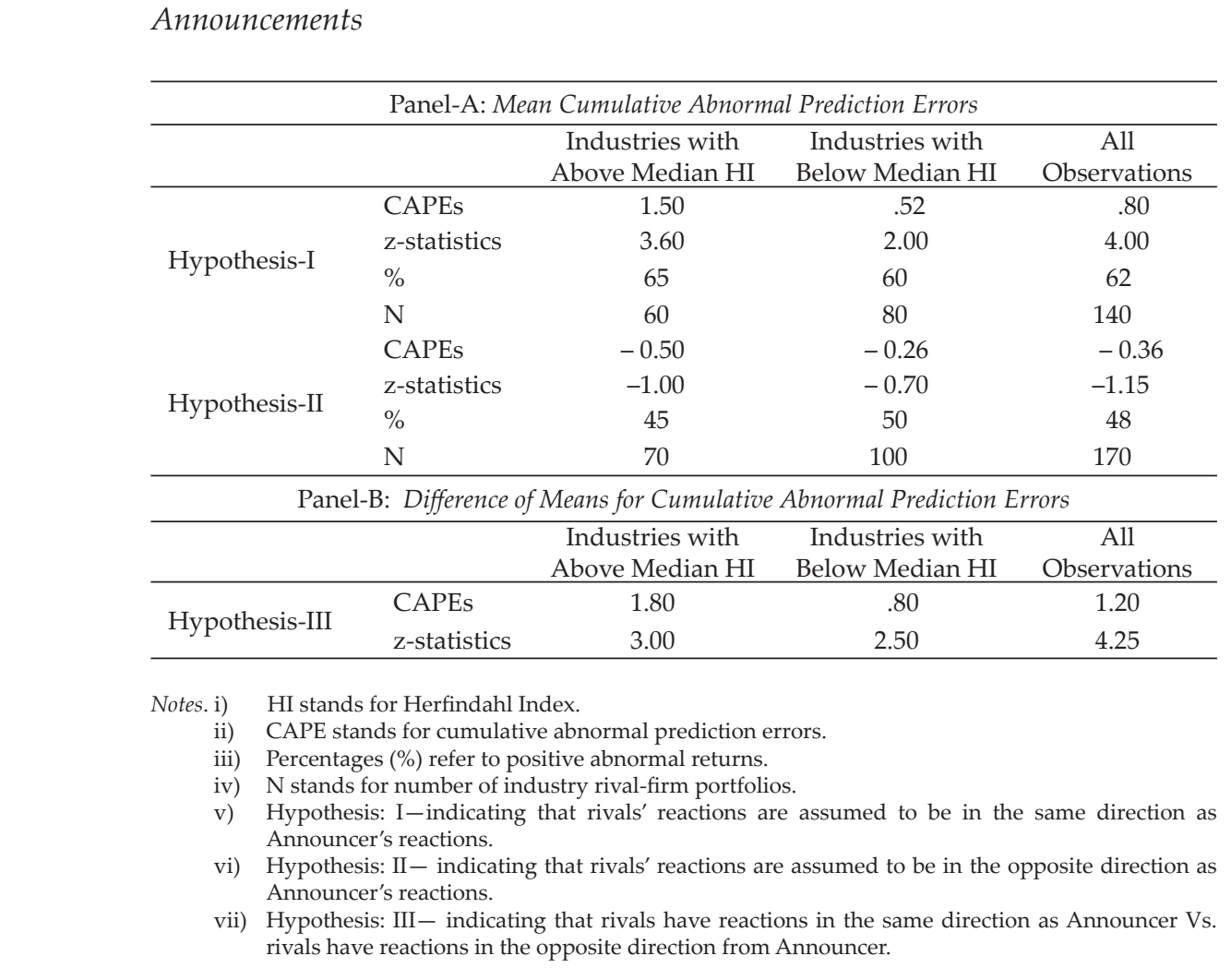

\section{Conclusion and Policy Implication}

4

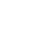

the industry's competitive balance. The extent of such offsetting competitive effects depends on several factors, including the relative market power of the firms involved, the ability of the rival to respond effectively to the announcer's revelation, and the extent of competition in the industry. The present paper had examined the stock price reactions on the part of industry firms to rivals' announcements of dividend. This study found that the observations of the announcing firms experience substantial abnormal returns at the time of their dividend change announcement. Observations of the announcers and those of the rival portfolio have positive abnormal returns at the time of announcements. Before dividend announcements, the

64 IJMS 17 (1), 55-67 (2010) 


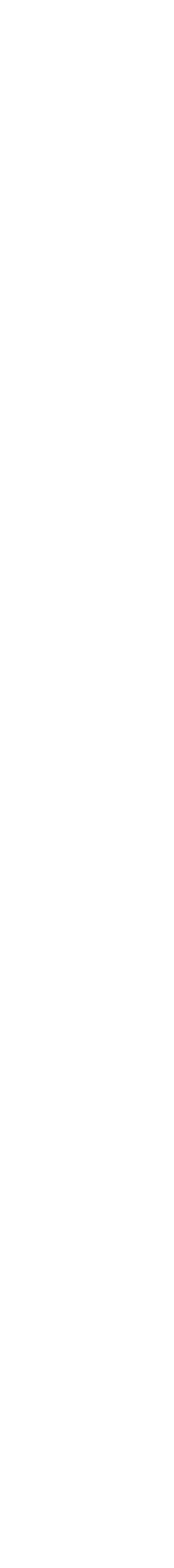

observations among the announcers and those of the rival portfolios also have positive abnormal returns in case of dividend increase. However, all the observations from both announcers and rival portfolios have overall positive abnormal returns around dividend announcements in case of dividend increase. On the other hand, the observations from both announcers and rival portfolio have negative abnormal returns both at the time of and before the announcements of dividend decrease. The present study indicated that significant stock price reactions occur for those rivals having competitive effects offsetting the contagion effects of the announcements of dividend. We may further extend our study by saying that the stronger rivals seem to be less likely to be placed at a competitive disadvantage when an announcer reveals a positive signal. Similarly, weaker rivals are least likely to gain a competitive advantage when an announcer reveals a negative signal. Finally, the study revealed that the industries with above median values of the Herfindahl Index experience a greater difference between the two types of rivals' reactions, indicating that these industries are stronger in terms of competitive effects than those with below median values of the Herfindahl Index.

\section{References}

Aharony, J., \& Swary, I. (1980). Quarterly dividend and earnings announcements and shareholders' returns: An empirical analysis. Journal of Finance, March, 1-12.

Asquith, P., \& Mullins. D. (1983). The impact of initiating dividend payments on shareholders' wealth. Journal of Business, January, 77-96

Bajaj, M., \& Vijh, A. (1990). Dividend clienteles and the information content of dividend changes. Journal of Financial Economics, August, 193-219.

Baginski, S. (1987). Intra-industry information transfers associated with management forecasts of earnings. Journal of Accounting Research, Autumn, 196-219.

Bowen, R., Castanias, R., \& Daley, L. (1983). Intra-industry effects of the accident at three mile island. Journal Financial and Quantitative Analysis, March, 87-112.

Bhattacharya, S. (1979). Imperfect information, dividend policy, and the 'Bird in the Hand' fallacy. Bell Journal of Economics, Spring, 259-270.

Dodd, P., \& Warner, J. (1983). On comparative governance: A study of proxy contests. Journal of Financial Economics, April, 401-438.

Eades, K., Hess, P., \& Kim, E. (1985). Market rationality and dividend announcements. Journal of Financial Economics, December, 3-34.

Eckbo, E. (1983). Horizontal mergers, collusion, and stockholder wealth. Journal of Financial Economics, April, 241-273.

IJMS 17 (1), 55-67 (2010) 
Firth, M. (1996). Dividend changes, abnormal returns, and intra-industry firm valuations. Journal Financial and Quantitative Analysis, June, 189212.

Foster, G. (1981). Intra-industry information transfers associated with earnings releases. Journal of Accounting and Economics, December, 201232.

Han. J., Wild, J., \& Ramesh, K. (1989). Managers earnings forecasts and intraindustry information transfers. Journal of Accounting and Economics, February, 3-33.

Hertzel, M. (1991). The effects of stock repurchases on rival firms. Journal of Finance, June, 707-716.

Howe, J., \& Shen, Y. (1998). Information associated with dividend initiations: Firm-specific or industry wide? Financial Management, Autumn, 17-26.

Jensen, G., \& Johnson, J. (1995). The dynamics of corporate dividend reductions. Financial Management, Winter, 31-51.

John, K., \& Williams, J. (1985). Dividends, dilution and taxes: A signaling equilibrium. Journal of Finance, September, 1053-1070.

Joh, G., \& Lee, C. (1992). Stock price response to accounting information in oligopoly. Journal of Business, July, 451-472.

Kalay, A. (1980). Signaling, information content, and the reluctance to cut dividend. Journal of Financial and Quantitative Analysis, December, 855869.

Kalay, A., \& Loewenstein, U. (1985). Predictable events and excess returns: The case of dividend announcements. Journal of Financial Economics, September, 423-449.

Kalay, A., \& Loewenstein, U. (1986). The information content of the timing of dividend announcements. Journal of Financial Economics, July, 373-388.

Kane, A., Lee, Y., \& Marcus A. (1984). Earnings and dividend announcements: Is there a corroboration effect? Journal of Finance, September, 10911099.

Lang, L., \& Litzenberger, R. (1989). Dividend announcements: Cash flow signaling vs. free cash flow hypothesis. Journal of Financial Economics, September, 181-192.

Lang, L., \& Stulz, R. (1992). Contagion and competitive intra-industry effects of bankruptcy announcements. Journal of Financial Economics, August, 45-60.

Marsh, T., \& Merton, R. (1987). Dividend behavior for the aggregate stock market. Journal of Business, January, 1-40.

Miller, M.H., \& Modigliani, F. (1966). Some estimates of the cost of capital to the electric utility industry, 1954-1957. American Economic Review, June, 333-391.

Miller, M.H., \& Rock, K. (1985). Dividend policy under asymmetric information. Journal of Finance, September, 1031-1051.

66 IJMS 17 (1), 55-67 (2010) 
Olsen, C., Dietrich, R., \& Bernard, V. L. (1985). Vertical information transfers: The association between retailers' sales announcements and suppliers' security returns. Journal of Accounting Research, Supplement, 144-166.

Paul, L., Starks L.T., \& Yoon, P.S. (1998). The relative importance of competition and contagion in intra-industry information transfers: An investigation of dividend announcements. Financial Management, Autumn, 5-16.

Pettit, R. (1972). Dividend announcements, security performance, and capital market efficiency. Journal of Finance, December, 993-1007.

Swary, I. (1986). Stock market reaction to regulatory action in the continental illinois crisis. Journal of Business, July, 451-473.

Venkatesh, P. C. (1989). The impact of dividend initiation on the information content of earnings announcements and returns volatility. Journal of Business, April, 175-197.

Slovin, M., Sushka, M., \& Poloncheck, J. (1991). Informational externalities of seasoned equity issues: Differences between banks and industrial firms. Journal of Financial Economics, August, 87-102.

Szewczyck, S. (1992). The intra-industry transfer of information inferred from announcements of corporate security offerings. Journal of Finance, December, 1935-1945.

Yoon, P., \& Starks, L. (1995). Signaling, investment opportunities, and dividend announcements. Review of Financial Studies, Winter, 9951018. 